\title{
Use of protein rich peas in the rabbit
}

Y. FRANCK $\left({ }^{1}\right)$, F. LEBAS( $\left.{ }^{2}\right)$, P. LESECQ $\left({ }^{3}\right)$, M. BOUGON( ${ }^{(3)}$ et M. LEUILLETT( ${ }^{(5)}$

(1) I.T.A.V.I., Sevvice technique, 28, rue du Rocher, 75008 Paris (France)

${ }^{\left({ }^{2}\right)}$ Laboratoire de Recherches sur l'élevage du Lapin,

Centre de Recherches de Toulouse, I.N.R.A. 3 I320 Castanet-Tolosan (France)

(3) U.F.A.C., Service technique, 95450 Vigny (France)

(4) Station expérimentale d'Aviculture, B.P. 9, 22440 Ploutragan (France)

${ }^{5}$ ) I.T.C.F., 8, avenue du Président-Wilson, 75Ix6 Paris (France)

A series of experiments were made to test a new source of proteins in France, the "Frima" peas, in the feeding of monogastric animals and particularly the rabbit.

This paper summarizes five trials achieved in different laboratories; four of them were done on fattening young rabbits with incorporation levels between o and $45 \mathrm{p}$. roo; the other on breeding rabbits with incorporation levels between $o$ and $40 \mathrm{p}$. roo.

The results showed that until incorporation levels of $30 \mathrm{p}$. Ioo, the growth rates of the fattening rabbits remained similar, though a slight non significant rise in the feed conversion ratio was observed as the incorporation level of peas increased in the diet (I02 and I03 p. IOO of the control at the incorporation level of $\mathrm{I}_{5}$ and $30 \mathrm{p}$. Ioo).

At the extreme incorporation level of $45 \mathrm{p}$. I 00 , used to determine an eventual toxic effect, the mortality was not affected, but the growth of the young rabbits was significantly reduced (93 p. Ioo of the control) while the feed conversion ratio slightly increased (I 04 p. I oo of the control

The control of the breeding dams receiving $40 \mathrm{p}$. I oo peas in their diet did not show any significant differences as compared with the controls; however, a negative effect on the ovulation rate of the does was noticed, but this has to be confirmed.

\section{Use of ground straw as a source of crude fibre in fattening rabbit feeding, a comparison of two crude fibre levels}

\author{
Y. FRANCK et J. P. COULMIN \\ I.T.A.V.I., Service technique, 28, rue du Rocher, 75008 Paris (France)
} animal.

The rabbit needs a ballast in its diet to prevent the risks of diarrhoea often mortal for the

This ballast is generally composed of crude fibre. However, the crude fibre sources ustually employed are of variable qualities or relatively expensive. Ground wheat straw available in large quantities was therefore used in replacement of dried lucerne at incorporation levels of $0-9.5$ p. Ioo and rg p. roo. Parallel to that, two dietary crude fibre levels were compared : $\mathrm{I} 2$ and 9 p. Ioo. This trial was achieved on 180 animals in individual cages and divided into 5 treatments.

When replacing lucerne by ground straw the growth rates remained identical : $34.0-34.5$ and $34.6 \mathrm{~g} / \mathrm{d}$, respectively for straw levels of $0-9.5$ and $\mathrm{i} 9 \mathrm{p}$. 100 .

On the contrary, with $9 \mathrm{p}$. Ioo crude fibre in the diet as compared with a level of $\mathrm{I} 2 \mathrm{p}$. IoO, a higher mortality rate (I9.4 versus $5.5 \mathrm{p}$. Ioo,) a similar growth $(34.4 \mathrm{~g} / \mathrm{d})$ were observed as well as a significant decrease in the feed intake, feed conversion ratio $(3.43$ versus 3.7 I $p$. Ioo) and carcass dressing percentage (6I.2 versus 62.4 p. Ioo). 